\title{
LEGAL BASIS FOR REGULATION OF THE PRIVATE SECURITY IN THE REPUBLIC OF MACEDONIA
}

\author{
Oliver BAKRESKI, PhD \\ Institute for Security, Defence and Peace Studies \\ E-mail: oliverbakreski@yahoo.com
}

\begin{abstract}
In the Republic of Macedonia, the private security is a significant factor in the overall interactions for building a beneficial security ambience in the country. Hence, it is not all at one how the private security activity will be regulated in the Republic of Macedonia, and also, it is a very important fact how the regulation would be implemented. The starting premise is that the existence of an appropriate regulation which will reflect the overall demands of the performers of the private security activty is an exceptional element in the designation of the relations in this sphere. In that notion, the regulation will signify legitimacy, legality and professionalism in the working of the subjects in the private security activity.
\end{abstract}

Key words: private security, private safety, activity, regulation, legitimacy.

\section{Why the regulation of the private security function is necessary?}

Some form of regulation influences the individuals on a daily basis. When a person travels to work with their automobile, meets numerous rules: owning a driver's license and insurance, vehicle maintenance and abidance of certain rules and norms. If he turns on the radio there will be radio stations, which are subjugated to rules, respectively, there is a certain frequency, which should be used, the number of commercials broadcasted is regulated as well as the topics, which are elaborated. Then, the person will arrive at work in a firm, which also needs to abid rules related to its working. The firm in which he works is also managed by certain behavior codex, which needs to be respected in order to survive and not be brought in 
a straitened condition. In other words, it is more than necessary to regulate all the issues in all the realms, including private security (Bruce G. \& Button Mark, 2004, p. 173-174).

Regulation has an essential significance from the aspect of legal working of the firm/company and appositely regulating it means that a very sensitive area would be covered in this sphere. Regulation could also help to foresee certain situations, which would enable a much better and more rational engagement of the resources. From this emanates that regulation is a key and useful element in the work of the firm/company itself, which enables the managing teams to establish an appropriate balance between the accomplished and planned activities. Without proper regulation, they will turn into blind observers of the process, which could lead to deviation of the planned goals and tasks, limited without the possibility to correct them and by that improve their work, as well as the work of the private subject.

In other words, the regulation could be interpreted as a plain formal mechanism of control, which is established in order to focus the behavior and enable universal application of the law. In principle, we claim that a greater regulative could lead to increased responsibility (0'Connor Lipper, Greenfield \& Boyle, 2004).

In general, regulation could contribute for improvement of the professionalism of private security companies, and increase the public trust. Professionalism is a categorical contour, which refers to certain values, skills, orientation and management. Principles of fair behavior, integrity, human rights awareness, responsibility and minimal use of force are the basic elements in every concept of democratic ruling. Professionalism cannot be involved in discriminatory, corrupted or violent exploitation of own power. The independence (limitation) which the private security sector has is based on the society's trust that this sector will accept part of the values conditioned by the democratic balance of ethical and professional management (Fluri P., Hadžić M. eds.. 2004)

Coming out of the embrace of professionalism would only result in a rude, corrupted and uncompetitive behavior, and in some cases even public scandals, which imposes the need for serious regulation in this sector (Born H., Caparini M., and Cole E., 2007, стр.5)

\section{Legal basis for regulation of the private security activity in the Republic of Macedonia}

It is generally considered that the regulation of the issues related with the private security in a legal form are one of the hardest, because they need to establish a balanced 


\section{Securiatity}

system of interactions between the subjects which actively take part in this realm: legal entities registered for performing the activity private security as a service provider; the recipients of the service (persons, firms); the Ministry of interior as a controller of the activities of the agencies; and the Chamber of the Republic of Macedonia for private security as a significant subject which needs to create preconditions for profession improvement.

Still, regardless of the complexity itself and the involvement of these issues, the private security in the Law for private security is foreseen through every aspect (content, structure, functionality and pragmatism) and also through the prism of certain solutions which simplify or complicate the work of the Security agencies, in order to reach the hardships itself, which are related for the ambit and the content of the private security.

If an analysis is made for Article 1 from the Law for private security, it will lead to a conclusion that the law in the segment of security involves a whole spectrum of security concerns which are connected with the terms for performing private security; conducting private security; private security for own purposes; mandatory private security; authorizations of private security personnel; working clothes and denotement of the private security employees; formation, authorizations and financing the Chamber of the Republic of Macedonia for private security; evidence, data and information protection; oversight, authorizations for secondary legislations and misdemeanor provisions.

According to the Law for private security, private security activities could be conducted by: legal entities registered in the Central register of the Republic of Macedonia and hold a private security license for providing services etc. The Law in the section of the terms, as stated in Article 8 of the Law it is strictly prescribed that private security could only be conducted in the form of providing services and for own purposes. What is emphasized is that security in the form of service provision is dominant, which is an amply indicator that this is the most dominant kind of private security as public service activity and with a commercial nature. The second kind of private security for own purposes is in fact self-protection which certain legal entities organize in accordance with the law, for protection of their employees, clients and other persons, as well as their own chattel and real estate.

Security involves a whole spectrum of issues regarding security, which is divided on physical and technical security. In Article 9, Paragraph 2 from the Law, physical security presupposes body protection, monitoring patrol security, transportation security and money transfer and other valuable shipments security and public gathering and event security, while technical security is protection of persons and property with technical means and devices in accordance with prescribed standards in order to prevent of illegal actions aimed toward 
persons and property, while private security for own needs is performed as a physical security such as body protection and monitoring security.

Regarding the performance of physical security, the security employee, as foreseen in the law has certain authorizations which would be in function: to make identification checks of persons during the entrance on the secured property; to warn a person to distance from the secured property, if the person remains in it unauthorized, respectively, warn the person which with its behavior or entry could jeopardize own or the security of others or could cause damage of the secured property; deny entrance to an uninvited person, as well as to forbid unauthorized recording or bringing devices and equipment for that purpose in the secured property; to detain and transmit a person caught up in perpetrating a criminal act to the police; to inspect persons, objects, vehicles and luggage and use coercive means. Further, in the dame article Paragraph 2, the territorial jurisdiction for their enforcement, which depends of the type of private security foreseen with Article 9 and Article 10 from this law? In that notion, private security employees employed in legal entities licensed for private security for own purposes these authorizations could be applied solely in the securing object or to the border of the securing space in terms of body protection and monitoring security (local authority). If these employees perform body protection to representatives from the legal entity outside from the securing object or the boundary of the securing space, they are authorized to enforce only the authorization for the use of coercive force (Article 45, Paragraph 1, Point 6) if their physical integrity or life is jeopardized, as well as the physical integrity and life of the securing person are threatened (functional authorization).

It means that in performing security activities, the security employee could apply certain coercive means with which a certain step forward is made in the direction of greater authorizations for the security personnel in conducting the tasks in the working realm, respectively with the use of certain coercive means, such as: physical force, rubber bat, excipients, chemical agents (sprays), firearms and trained kanine.

If the new changes are been analyzed with which it is foreseen to strengthen certain authorizations, especially regarding the methods for coercion, it will be witnessed that certain bold steps are made which basically should be understood solely as a way for a more efficient task conduct and it should assist the work on the public security sector as well in the common efforts for dealing the risks and threats aimed toward the citizens and the country.

Regarding the performance of technical security, certain adjustments are made in order to further precise this segment. So, in the new Law for private security is is anticipated technical security to be conducted with the use of technical means and devices in order to prevent illegal actions directed toward persons and property, and especially for the protection 


\section{Securiaty}

of unauthorized utilization and expropriation of securing items; unauthorized insertion of firearms, explosives, radioactive, combustible and toxic materials; breaking into, diversion or violent attack on the secured object; unauthorized access to data and records; money and other valuables transportation vehicles assault and security employees conducting money and other valuables transportation raids.

An individual who holds for private security is decisive and strictly prescribes that private security could only perform the Law: a private security license and private security identification document. The Chamber issues the security license and identification document for security, if the individual fulfils the conditions designated with this law. With the prescription of such terms, it is more than logical that not anybody could perform activities from the private security realm, yet there are certain preconditions to be met in order to realize such possibility. The law treats license as a proof for capability for conducting private security and permission for professional practicing with tasks and professional duties from the private security realm. The license for private security is a precondition for obtaining a private security identification document, which the licensed candidate gets by establishing employment as a security employee in some legal entity, which holds a license for performing private security. The license is a proof for a passed examination after a conducted training la sort of a diploma) which is obtained permanently, while the identification card is tied with the employment, hence, based on a license, the candidate, in his working career, can acquire identification cards from various security agencies, but must not have more than one identification card because has an obligation to return it after the expiration of the working contract.

In the Republic of Macedonia the statistical data from the Central register of the Republic of Macedonia guide to the facts that private protection activities are performed by 64 subjects with a 2171 number of employees, while the activity service for protection in addition with security systems is obtained by 1134 employees, and in the part of investigation activities, there are 10 subjects registered with 82 employees.

\section{Conclusion}

The need for regulation of the private security is more than necessary, because it signifies the establishment of a legal status of the performers of the private security activity in the direction of legally established tasks. This should not counterpoise a significant problem because it does not adjustment with the standards in this sphere with other countries, 
respectively; it does not depend on international negotiations, which often means that the introduction of laws counterpoises something more than the lowest common denominator.

The case analysis with our country showed that the reasons for designation of this activity are classified in the following manner: designating the legal framework in order to regulate the activity private security, framework for the authorizations which would mean, in specific cases, suspension of human rights and freedoms, regulation of the work and duties, protection of privacy intact of persons which communicate with this sector, protection of the legal entities which intended to perform private security activities, prevention of the use of private security agencies for political purposes, suppression of protests etc, organization of the issues regarding the roles and the realms of cooperation; enabling the public to clearly and transparently identify the members of the police from the private security agencies employees; providing oversight over the use of authorizations by the security employees; exclusion of criminal and convicted persons from this sector by establishing license criteria, enabling equal standards in the procedures of the security agencies; organizing the method of control for possession of fire arms in the firms providers of security services; oversight over the work of the security agencies, establishment of minimal working conditions etc.

\section{Literature}

1. Ahić J., Sistemi privatne sigurnosti, Srajevo, 2009

2. Бакрески 0., Даничиќ М., Кешетовиќ Ж., и Митевски С.: Приватна безбедност, Комора на

Република Македонија за приватно обезбедување, Скопје, 2015.

3. Бакрески 0., и др. Коментар на законот за приватно обезбедување, Комора на Република Македонија за приватно обезбедување, Скопје, 2014.

4. Buzati, Anne-Marie, European Practices of Regulation of PMSCs and Recommendations for Regulation of PMSCs through International Legal Instruments, The Geneva Centre for Democratic Control of Armed Forces, 2008.

5. Born H., Caparini M. and Cole E.: Regulating Private Security in Europe: Status and Prospects, Geneva Centre for the Democratic Control of Armed Forces (DCAF), Policy Paper - №20, 2007.

6. Bruce G. and Button M.: Private Security, Palgrave Macmillan, New York, 2004.

7. Private Security, Palgrave Macmillan, New York, 2004. 


\section{Securiaty}

8. Sourcebook on Security Sector Reform, Fluri P., Hadžić M. (eds.) Geneva Centre for the Democratic Control of Armed Forces/Centre for Civil-Military Relations, Belgrade, Geneva/Belgrade, 2004

9. Heywood, A., Politics, Palgrave Macmillan Ltd, 2002.

10. Hans Born, Marina Caparini, and Eden Cole, Regulating Private Security in Europe: Status and Prospects, Geneva Centre for the Democratic Control of Armed Forces (DCAF), Policy Paper - №20, 2007

11. Sheehy Benedict, Maogoto Jackson and Newell Virginia, Legal Control of the Private Military Corporation, Palgrave Macmillan, Now York, 2009. 